\title{
HUBUNGAN PENGETAHUAN DAN SIKAP IBU DENGAN TINDAKAN PEMBERIAN ASI EKSKLUSIF DI PUSKESMAS RAMBUNG KECAMATAN BINJAI SELATAN KOTA BINJAI TAHUN 2017
}

\author{
Correlation of Women's Knowledge and Attitude with Breastfeeding with Exclusive ASI at \\ Rambung Puskesmas, Binjai Selatan Subdistrict Binjai in 2017
}

\author{
Nurleli ${ }^{1}$, Jenny Marlindawani Purba ${ }^{2}$, Rinawati Sembiring ${ }^{2}$ \\ ${ }^{1}$ Program Studi Pasca Sarjana Kesehatan Masyarakat Universitas Sari Mutiara Indonesia \\ Email: nurleliabahani@yahoo.com \\ ${ }^{2}$ Dosen Program Studi Pasca Sarjana Kesehatan Masyarakat \\ Universitas Sari Mutiara Indonesia \\ Email: jhouan_702@hotmail.com
}

\begin{abstract}
Abstrak
ASI eksklusif adalah pemberian hanya ASI saja tanpa makanan dan minuman lain baik berupa susu formula,jeruk, madu, air teh dan air putih serta tanpa tambahan makanan padat seperti pisang, bubur susu, biskuit, bubur nasi dan nasi tim. ASI merupakan makanan terbaik bagi kelangsungan hidup bayi di usia 6 bulan, dan melanjutkan pemberian ASI sampai umur 2 tahun. Tujuan penelitian adalah untuk mengetahui hubungan pengetahuan dan sikap ibu dengan tindakan pemberian ASI eksklusif. Jenis penelitianini adalah analitik observasional dengan pendekatan cross sectional. Populasi dalam penelitian ini adalah seluruh ibu yang memiliki anak usia 6 bulan sampai dengan 12 bulan di Puskesmas Rambung yakni 687 orang, dengan teknik pengambilan sampel consecutive sampling dan penentuan sampel dilakukan dengan menggunakan rumus Lameshow sehingga ada 90 sampel penelitian yang terdiri dari ibu menyusui. Analisis data dilakukan dengan uji chi-square pada tingkat kepercayaan 95\% (0.05). Hasil penelitian memperlihatkan bahwa pengetahuan ibu tentang ASI eksklusif memiliki hubungan signifikan dengan tindakan pemberian ASI eksklusif $(\mathrm{p}<0.05)$, sikap juga memiliki hubungan signifikan dengan tindakan pemberian ASI eksklusif ( $\mathrm{p}<0.05)$. Berdasarkan hasil penelitian dapat disimpulkan bahwa pendidikan erat hubungannya dengan pengetahuan, sikap dan tindakan pemberian ASI eksklusif sehingga semakin tinggi pendidikan, semakin baik pula pengetahuan, sikap dan tindakan pemberian ASI eksklusif. Kepada Puskesmas Rambung Kecamatan Binjai Selatan, diharapkan untuk lebih meningkatkan promosi kesehatan dengan cara mensosialisasikan pentingnya ASI eksklusif bagi bayi sehingga dapat menambah pengetahuan ibu tentang tindakan pemberian ASI eksklusif sehingga tindakan pemberian ASI eksklusif dapat lebih dimaksimalkan.
\end{abstract}

Kata kunci : Pengetahuan, sikap, tindakan memberikan ASI eksklusif

\begin{abstract}
Exclusive ASI (breast milk) is breastfeeding with only breast milk, without giving other supplements like orange juice, honey, tea, or plain water and without other solid food like banana, milk porridge, biscuit, rice porridge, and rice cooked in a pan of water (au bain-marie). It is the best food for the survival of a 0-6 month-old baby, and it is better to continually give until the baby is 2 years old. The objective of this research was to find out the correlation of women's knowledge and attitude with breastfeeding with exclusive ASI. The research used observational analytic method with sectional design. The population was 687 women who breastfed their 6-12 month-old babies at Rambung Puskesmas, and 90 of them were used as the samples, taken by using consecutive sampling technique and Lame show formula. The data were analyzed by using chi square test at the significance level of $95 \%(0.05)$. The result of the research showed that there was significant correlation of the respondents' knowledge $(p<0.05)$ and attitude $(p<0.05)$ with breastfeeding with exclusive ASI. It could be concluded that education was closely related to knowledge, attitude, and action in breastfeeding with exclusive ASI. It is recommended that the Head of Rambung Puskesmas, Binjai Selatan Subdistrict increase health promotion by socializing the importance of exclusive ASI for babies so that women can improve their knowledge of breastfeeding with exclusive ASI maximally.
\end{abstract}

Keywords: Knowledge, Attitude, Action, Breastfeeding with Exclusive ASI

Jurnal Riset Hesti Medan, Vol. 3, No. 1 Januari-Juni 2018 


\section{PENDAHULUAN}

Pemberian Air Susu Ibu (ASI) atau menyusui bayi dilakukan di berbagai lapisan masyarakat diseluruh dunia, karena banyak manfaat yang diperoleh dari ASI Eksklusif dan praktik menyusui selama 2 tahun. Pemberian ASI Eksklusif merupakan cara pemberian makanan yang sangat tepat dan kesempatan terbaik bagi kelangsungan hidup bayi di usia 6 bulan, dan melanjutkan pemberian ASI sampai umur 2 tahun (Harnowo, 2012).

World Health Organization (WHO), merekomendasikan bahwa langkah terbaik dalam menjaga kesehatan bayi dan ibunya adalah pemberian ASI eksklusif setidaknya sampai 6 bulan. ASI eksklusif bukan hanya semata didasarkan pada pertimbangan bahwa ASI eksklusif adalah makanan terbaik bagi bayi, akan tetapi juga menjadi bagian integral dari proses reproduksi yang memiliki implikasi penting bagi kesehatan ibu yang menyusui. Dan pemberian ASI selama 6bulan justru mendorong pertumbuhan bayi yang optimal (Khairiyah, 2013). The World Allience for Breastfeeding Action (WABA) memperkirakan 1 juta bayi dapat diselamatkan setiap tahunnya bila diberikan ASI pada 1 jam pertama kelahiran, kemudian dilanjutkan ASI Eksklusif sampai dengan 6 bulan, karena ASI selain mengandung gizi yang cukup, lengkap, juga mengandung imun untuk kekebalan tubuh bayi. World Health Organisation (WHO) menyatakan hanya $64,7 \%$ ibu menyusui didunia yang memberikan ASI secara Eksklusif. (Meutia, 2009).

Dari hasil penelitian United Nation Child's Fund (UNICEF) dari tahun 2005 hingga 2011 didapati bayi Indonesia yang mendapat ASI Eksklusif selama 6 bulan pertama ialah sebanyak 32\% dan didapati $50 \%$ anak diberikan ASI Eksklusif sehingga usia 23 bulan. Tetapi persentase ini masih rendah bila dibandingakan dengan negara berkembang lain seperti Bangladesh didapati $43 \%$ anak diberikan ASI Eksklusif selama 6 bulan dan 91\% anak mendapat ASI sehingga usia 23 bulan (UNICEF, 2011).Begitu pula yang terjadi di Indonesia, data dari Sentra laktasi Indonesia mencatat bahwa berdasarkan survei demografi dan kesehatan Indonesia 2007-2010, hanya $48 \%$ ibu yang memberikan ASI eksklusif. Di Indonesia, rata-rata ibu memberikan ASI eksklusif hanya 2 bulan, sementara pemberian susu formula meningkat
3 kali lipat. Dari data Survey Demografi dan Kesehatan Indonesia (SDKI) tahun 2012 menunjukan bahwa sebanyak $27 \%$ bayi di Indonesia mendapatkan ASI eksklusif sampai dengan umur 4-5 bulan. Sedangkan Riset Kesehatan Dasar (Riskesdas) tahun 2013, angka pemberian ASI eksklusif pada bayi berumur 0-6 bulan hanya mencapai angka $30,2 \%$. Angka yang relatif masih sedikit, padahal dengan ASI dan menyusui baik ibu dan bayinya akan mendapatkan banyak manfaat. Bahkan hal ini juga berimbas ke lingkungan, masyarakat, bangsa, dan Negara. (Kemenkes RI, 2013).

Mengacu pada target renstra pada tahun 2015 yang sebesar 39\%, maka secara nasional cakupan pemberian ASI eksklusif pada bayi usia kurang dari enam bulan sebesar 55,7\% telah mencapai target. Menurut provinsi, kisaran cakupan ASI eksklusif pada bayi umur 0-6 bulan antara 26,3\% (Sulawesi Utara) sampai 86,9\% (Nusa Tenggara Barat). Dari 33 provinsi yang melapor, sebanyak 29 di antaranya $(88 \%)$ berhasil mencapai target renstra 2015. Jadi ada 4 provinsi yang belummencapai target, termasuk Sumatera Utara yakni 33,0\%

Berdasarkan Profil Dinas Kesehatan Sumatera Utara, cakupan persentasi bayi yang diberi ASI eksklusif dari tahun 2010-2014 cenderung menunjukkan peningkatan, dan cakupan tahun 2014 merupakan pencapaian tertinggi dari kurun waktu 5 tahun ini. Walaupun demikian pencapaian ini belum mampu mencapai target nasional. Hasil Riskesdas 2013 menunjukkan angka untuk proses menyusui kurang dari satu jam (IMD) di Sumatera Utara hanya 22,9\%. Sedangkan untuk wilayah Kota Binjai cakupan ASI eksklusif cukup rendah yaitu $11,99 \%$. Kota Binjai merupakan salah satu wilayah di Sumatera Utara yang cakupan ASI eksklusifnya cukup kecil dibandingkan dengan wilayah lainnya.

ASI ekskusif merupakan makanan pertama, utama dan terbaik bagi bayi, yang bersifat alamiah. ASI mengandung berbagai zat gizi yang dibutuhkan dalam proses pertumbuhan dan perkembangan bayi (Prasetyono, 2009). Khasiat ASI begitu besar bagi bayi, ASI eksklusif adalah makanan dengan kandungan gizi yang paling sesuai untuk kebutuhan bayi, melindungi dari berbagai infeksi dan memberikan hubungan 
kasih sayang yang mendukung semua aspek perkembangan bayi termasuk kesehatan dan kecerdasan bayi. Bagi ibu, memberikan ASI secara eksklusif dapat mengurangi pendarahan pada saat persalinan, menunda kesuburan dan meringankan beban ekonomi. (Roesli, 2008).

Berdasarkan hasil survei awal yang peneliti lakukan pada 10 orang ibu nifas, di Puskesmas Rambung, diperoleh gambaran pengetahuan ibu bahwa semua responden menyadari dan tahu akan pentingnya ASI dapat meningkatkan kekebalan tubuh bayi. Ibu juga beranggapan bahwa bayi yang diberikan ASI akan lebih kuat dan tidak mudah terserang penyakit dari bayi yang tidak diberi ASI eksklusif.

\section{METODE PENELITIAN}

Rancangan penelitian ini adalah analitik observasional dengan pendekatan cross sectional dimana data yang menyangkut variabel bebas atau resiko dan variable terikat atau variable akibat, akan dikumpulkan dalam waktu yang bersamaan (Notoatmodjo, 2010).

Penelitian ini dilaksanakan di Puskesmas Rambung. Alasan pemilihan lokasi penelitian ini karena berdasarkan hasil survei awal diperoleh gambaran bahwa pengetahuan dan sikap ibu menyusui masih rendah mengenai ASI eksklusif, dan di Puskesmas RambungKecamatan Binjai Selatan Kota Binjai belum pernah dilakukan penelitian mengenai ASI eksklusif. Penelitian akan dilakukan pada bulan Juni 2017

Populasi dalam penelitian ini adalah seluruh ibu yang berkunjung ke posyandu di Puskesmas RambungKecamatan Binjai Selatan, Kota Binjai yakni 687 orang. Sample yang diambil menggunakan consecutive sampling dengan kriteria inklusi sebagai berikut: 1. Wanita yang telah memiliki anak berusia 6 sampai 24 bulan dan datang ke Posyandu. 2. Bersedia ikut serta dalam penelitian setelah mendapatkan penjelasan mengenai apa yang akan dilakukan dan menandatangani informed consent.

Uji validitas dan realibilitas dilakukan pada ibu-ibu di wilayah kerja Puskesmas Rambung Kecamatan Binjai Selatan sebanyak 30 orang. Hasil uji validitas dan reliabilitas kuesioner dapat dilihat pada lampiran. Analisis univariat dilakukan untuk mengetahui secara deskriptif variabel yang diteliti ke dalam tabel distribusi frekuensi untuk mengetahui karakteristik dan distribusi data.

Analisis bivariat dilakukan untuk mengetahui hubungan masing-masing variabel independen dengan variabel dependen. Analisis dilakukan dengan uji statistik dengan menggunakan uji Chi Square $\left(\chi^{2}\right)$ dengan tingkat kemaknaan $\mathrm{p}>0,05$.

\section{HASIL PENELITIAN \\ Gambaran Umum Puskesmas Rambung Kecamatan Binjai Selatan}

Kecamatan Binjai Selatan dengan luas wilayah 2.995.50 Ha dengan jumlah Penduduk pada tahun 200946.135 orang terdiri dari Laki-laki 23.142 orang dan Wanita 22.993 orang. Kecamatan Binjai Selatan membawahi 8 Kelurahan yaitu: Kelurahan Rambung Dalam, Kelurahan Tanah Merah, Kelurahan Rambung Timur, Kelurahan Tanah Seribu, Kelurahan Bhakti Karya, Kelurahan Binjai Estate, Kelurahan Pujidadi, dan Kelurahan Rambung Barat.

Puskesmas Rambung berada di Jalan Jamin Ginting No. 111 Kelurahan Rambung Barat, Kecamatan Binjai Selatan. Wilayah Kerja Puskesmas Rambung memiliki batas:

a. Sebelah Timur berbatasan dengan : Kelurahan Mencirim, Kecamatan binjai Timur.

b. Sebelah Barat berbatasan dengan: Kelurahan Binjai Estate, kecamatan Binjai Selatan

c. Sebelah Selatan berbatasan dengan: Kuala Mencirim, Kabupatan Langkat.

d. Sebelah Utara berbatasan dengan : Kelurahan Setia, Kecamatan Binjai Kota.

Mayoritas penduduk yang bertempat tinggal di wilayah Puskesmas rambung adalah beragama Islam. Luas areal pertanian di wilayah kerja Puskesmas Rambung sekitar $105 \mathrm{Ha}$ atau sama dengan $44,5 \%$ dari luas wilayah kerja Puskesmas. Areal pertanian ini berupa sawah yang mempunyai irigasi dan sawah tadah hujan. Sesuai dengan kondisinya, penduduk daerah mengusahakan berbagai pekerjaan seperti peternakan (peternak ayam), kerajinan home industri, industri besar (bengkel las), jasa pemerintah / non pemerintah, PNS, pegawai swasta, pegawai swasta, pegawai BUMN/ BUMD, pensiunanABRI/Polri, pedagang (toko, warung, kios). 
Ada 16 posyandu yang ada di Puskesmas Rambung dibagi dalam tiga puskesmas pembantu yaitu Rambung dalam enam posyandu, Rambung Barat lima posyandu dan Rambung Timur lima posyandu. Masingmasing posyandu dibantu oleh kader-kader yang sudah dibina oleh petugas puskesmas sebelumnya. Berbagai kegiatan diposyandu dilaksanakan sesuai dengan jadwal yang sudah ditentukan sebelumnya seperti pemberian imunisasi, penyuluhan (KB, PHB dan ASI Eksklusif) pemberian Vitamin A dan obat cacing.

\section{Analisis Univariat}

Karakteristik responden dalam penelitian ini meliputi umur, pendidikan dan pekerjaan dengan distribusi frekuensi sebagai berikut:

\section{Karakteristik Responden Berdasarkan Umur, Pendidikan dan Pekerjaan}

Umur responden dalam penelitian ini dikategorikan kedalam 3 tingkatan yakni $<25$ tahun, 25-30 tahun dan lebih dari 30 tahun, Pendidikan responden dalam penelitian ini dikategorikan kedalam 5 tingkatan yakni SD, SMP, SMA, Diploma dan sarjana dan Pekerjaan responden dalam penelitian ini dikategorikan kedalam lima jenis yakni pegawai swasta,wiraswasta, pedagang, IRT dan PNS dengan distribusi frekuensi sebagai berikut;

Tabel 1. Karakteristik Responden Berdasar-kan Umur, Pendidikan dan Pekerjaan

\begin{tabular}{|c|c|c|c|}
\hline No & Umur & $\mathbf{f}$ & $\%$ \\
\hline 1 & $<25$ tahun & 9 & 10.0 \\
\hline 2 & $25-30$ tahun & 50 & 55.6 \\
\hline \multirow[t]{2}{*}{3} & $>30$ tahun & 31 & 34.4 \\
\hline & Total & 90 & 100.0 \\
\hline No & Pendidikan & f & $\%$ \\
\hline 1 & SD & 10 & 11.1 \\
\hline 2 & SMP & 16 & 17.8 \\
\hline 3 & SMA & 46 & 51.1 \\
\hline 4 & Diploma & 14 & 15.6 \\
\hline \multirow[t]{2}{*}{5} & Sarjana & 4 & 4.4 \\
\hline & Total & 90 & 100.0 \\
\hline No & Pekerjaan & f & $\%$ \\
\hline 1 & Pegawai swasta & 7 & 7.8 \\
\hline 2 & Wiraswasta & 7 & 7.8 \\
\hline 3 & Pedagang & 20 & 22.2 \\
\hline
\end{tabular}

\begin{tabular}{ccccc}
\hline 4 & IRT & & 53 & 58.9 \\
5 & PNS & & 3 & 3.3 \\
\hline & & Total & $\mathbf{9 0}$ & $\mathbf{1 0 0 . 0}$ \\
\hline
\end{tabular}

Sumber : Hasil penelitian 2017 (data diolah)

Berdasarkan karakteristik umur responden memperlihatkan bahwa dari 90 orang responden penelitian, 9 orang $(10.0 \%)$ berumur dibawah 25 tahun, 50 orang $(55.6 \%)$ berumur antara 25-30 tahun dan 31 orang (34.4\%) berumur lebih dari 30 tahun. Dengan demikian, mayoritas responden berumur antara 25-30 tahun yakni sebanyak 50 orang $(55.6 \%)$. Pada karakteristik Pendidikan memperlihatkan bahwa dari 90 orang responden penelitian, 10 orang $(11.1 \%)$ berpendidikan SD, 16 orang (17.8\%) berpendidikan SMP, 46 orang $(51.1 \%)$ berpendidikan SMA, 14 orang (15.6\%) berpendidikan diploma, dan 4 orang (4.4\%) berpendidikan sarjana. Dengan demikian, mayoritas responden berpendidikan SMA yakni sebanyak 46 orang (51.1\%). Sedangkan pada karakteristik Pekerjaan responden memperlihatkan bahwa dari 90 orang responden penelitian, 7 orang $(7.8 \%)$ bekerja sebagai pegawai swasta, 7 orang $(7.8 \%)$ bekerja sebagai wiraswasta, 20 orang $(22.2 \%)$ bekerja sebagai pedagang, 53 orang $(58.9 \%)$ bekerja sebagai IRT dan 3 orang (3.3) bekerja sebagai PNS (pegawai negeri sipil. Dengan demikian, mayoritas responden bekerja sebagai IRT yakni sebanyak 53 orang (58.9\%).

\section{Pengetahuan}

Pengetahuan dalam penelitian ini diukur dengan 20 item pertanyaan dengan distribusi jawaban terlampir. Berdasarkan hasil rekapitulasi jawaban responden atas ke-20 pertanyaan tentang pengetahuan, maka pengetahuan dikategorikan kedalam 2 kategori yakni kurang (jika mendapat skor 0-10) dan baik (jika mendapat skor 11-20).

\section{Tabel 2. Kategori Pengetahuan}

\begin{tabular}{clcc}
\hline No & Pengetahuan & f & \% \\
\hline 1 & Baik & 55 & 61.1 \\
2 & Kurang & 35 & 38.9 \\
\hline \multicolumn{2}{c}{ Total } & $\mathbf{9 0}$ & $\mathbf{1 0 0 . 0}$ \\
\hline
\end{tabular}

Sumber : Hasil penelitian 2017 (data diolah)

Tabel 2 memperlihatkan bahwa dari 90 orang responden penelitian, 55 orang $(61.1 \%)$ memiliki pengetahuan yang baik tentang ASI eksklusif dan 35 orang (38.9\%) memiliki 
pengetahuan kurang. Dengan demikian, mayoritas responden memiliki pengetahuan baik tentang ASI eksklusif yakni sebanyak 55 orang $(61.1 \%)$.

\section{Sikap}

Sikap dalam penelitian ini diukur dengan 20 item pernyataan dengan distribusi jawaban terlampir. Berdasarkan hasil rekapitulasi jawaban responden atas ke-20 pertanyaan tentang sikap, maka sikap dikategorikan kedalam 2 kategori yakni negatif (jika mendapat skor 20-60) dan positif (jika mendapat skor 61-100).

\section{Tabel 3. Kategori Sikap}

\begin{tabular}{cccc}
\hline No & Sikap & f & \% \\
\hline 1 & Positif & 51 & 56.7 \\
2 & Negatif & 39 & 43.3 \\
\hline & Total & $\mathbf{9 0}$ & $\mathbf{1 0 0 . 0}$ \\
\hline
\end{tabular}

Sumber : Hasil penelitian 2017 (data diolah)

Tabel 3 memperlihatkan bahwa dari 90 orang responden penelitian, 51 orang $(56.7 \%)$ memiliki sikap yang positif tentang ASI eksklusif dan 39 orang (43.3\%) memiliki sikap negatif. Dengan demikian, mayoritas responden memiliki sikap positif tentang ASI eksklusif yakni sebanyak 51 orang (56.7\%).

\section{Tindakan Pemberian ASI eksklusif}

Tindakan pemberian ASI eksklusif diukur dengan 1 item pertanyaan dengan distribusi frekuensi sebagai berikut :

Tabel 4. Kategori Tindakan Pemberian ASI Eksklusif

\begin{tabular}{cccc}
\hline No & $\begin{array}{c}\text { Pemberian ASI } \\
\text { Eksklusif }\end{array}$ & f & \% \\
\hline 1 & ASI eksklusif & 57 & 63.3 \\
2 & $\begin{array}{l}\text { Tidak ASI } \\
\text { eksklusif }\end{array}$ & 33 & 36.7 \\
\hline & Total & $\mathbf{9 0}$ & $\mathbf{1 0 0 . 0}$ \\
\hline
\end{tabular}

Sumber : Hasil penelitian 2017 (data diolah)

Tabel 4 memperlihatkan bahwa dari 90 orang responden penelitian, 57 orang $(63.3 \%)$ memberi ASI eksklusif dan 33 orang (36.7\%) tidak memberi ASI eksklusif. Dengan demikian, mayoritas responden memberi ASI Eksklusif yakni sebanyak 57 orang (63.3\%).

\section{Analisis Bivariat}

Analisis bivariat dilakukan untuk mengidentifikasi hubungan variabel independen (pengetahuan dan sikap) dengan variabel dependen (tindakan pemberian ASI eksklusif).

\section{Hubungan Pengetahuan dengan Pemberian ASI Eksklusif}

Hubungan antara pengetahuan dengan tindakan pemberian ASI eksklusif dilakukan dengan menggunakan uji chi-square pada tingkat kepercayaan $95 \% \quad(p<0.05)$ yang memperlihatkan hasil sebagai berikut :

Hasil uji chi-square memperlihatkan bahwa pada table contingency $2 \times 2$, tidak ada yang memiliki nilai harapan (expected value $E$ ) kurang dari 5, sehingga nilai p-value yang dipergunakan adalah nilai contingency correction $t_{- \text {count }}=32.302$ dengan $\mathrm{p}$-value 0.000 , lebih kecil dari 0.05 , sehingga dapat disimpulkan bahwa pengetahuan memiliki hubungan signifikan dengan tindakan pemberian ASI eksklusif.

Hasil tabulasi silang pada tabel 6 memperlihatkan bahwa dari 51 responden dengan sikap positif, 49 orang (96.1\%) memberi ASI eksklusif dan 2 orang (3.9\%) tidak memberi ASI Eksklusif. Selanjutnya dari 39 responden dengan sikap negatif, 8 orang (20.5\%) memberi ASI eksklusif dan 31 orang (79.5\%) tidak memberi ASI eksklusif. Dengan demikian, mayoritas responden yang memberi ASI eksklusif adalah yang memiliki sikap positif yakni sebanyak 49 orang (96.1\%). Namun ada tujuh butir soal yang memiliki jawaban yang kurang tepatnya lebih besar, hal ini disebabkan kurangnya sosialisasi yang diberikan oleh petugas puskesmas yang bertugas di bagian promosi kesehatan khususnya untuk promosi ASI eksklusif

Hasil uji chi-square memperlihatkan bahwa pada table contingency $2 \times 2$, tidak ada yang memiliki nilai harapan (expected value $E$ ) kurang dari 5, sehingga nilai p-value yang dipergunakan adalah nilai contingency correction $t_{\text {- } \text { count }}=51.137$ dengan $\mathrm{p}$-value 0.000 , lebih kecil dari 0.05 , sehingga dapat disimpulkan bahwa sikap memiliki hubungan signifikan dengan tindakan pemberian ASI eksklusif

Hubungan Pengetahuan dengan Pendidikan

Hubungan antara pengetahuan dengan pendidikan diuji dengan menggunakan uji chisquare pada tingkat kepercayaan 95\% $(\mathrm{p}<0.05)$ dengan sebagai berikut : 
Tabel 5. Hubungan Antara Pengetahuan dengan Pendidikan

\begin{tabular}{|c|c|c|c|c|}
\hline \multirow{3}{*}{$\begin{array}{l}\text { Pendidi- } \\
\text { kan }\end{array}$} & \multicolumn{4}{|c|}{ Pengetahuan } \\
\hline & \multicolumn{2}{|c|}{ Baik } & \multicolumn{2}{|c|}{ Kurang } \\
\hline & $\mathrm{n}$ & $\%$ & $\mathbf{n}$ & $\%$ \\
\hline SD & 3 & 30.0 & 7 & 70.0 \\
\hline SMP & 11 & 68.8 & 5 & 31.3 \\
\hline SMA & 25 & 54.3 & 21 & 45.7 \\
\hline Diploma & 12 & 85.7 & 2 & 14.3 \\
\hline Sarjana & 4 & $\begin{array}{c}100 . \\
0\end{array}$ & 0 & 0.0 \\
\hline Total & 55 & 61.1 & 35 & 38.9 \\
\hline
\end{tabular}

Sumber : Hasil penelitian 2017 (data diolah)

Hasil tabulasi silang pada tabel 5 memperlihatkan bahwa dari 10 responden berpendidikan SD, hanya 3 orang $(30.0 \%)$ yang berpengetahuan baik dan 7 orang $(70.0 \%)$ berpengetahuan kurang. Selanjutnya, dari 16 responden berpendidikan SMP, 11 orang $(68.8 \%)$ berpengetahuan baik, dan 5 orang (3.3\%) berpengetahuan kurang. Dari 46 responden berpendidikan SMA, 25 orang (54.3\%) berpengetahuan baik dan 21 orang (45.7\%) berpengetahuan kurang. Dari 14 orang berpendidikan diploma, 12 orang $(85.7 \%)$ berpengetahuan baik dan 2 orang (14.3\%) berpengetahuan kurang. Dari 4 orang berpendidikan sarjana, seluruhnya berpengetahuan baik $(100 \%)$.

Hasil uji chi-square memperlihatkan bahwa pada table contingency $2 \times 2$, ada yang memiliki nilai harapan (expected value E) kurang dari 5, sehingga nilai p-value yang dipergunakan adalah nilai Fisher $t_{-{ }_{\text {count }}}=6.629$ dengan $\mathrm{p}$-value -0.010 , lebih kecil dari 0.05 , sehingga dapat disimpulkan bahwa pengetahuan memiliki hubungan signifikan dengan pendidikan. Dengan kata lain, semakin tinggi pendidikan semakin baik pengetahuan.

\section{Hubungan Sikap dengan Pendidikan}

Hubungan antara sikap dengan pendidikan diuji dengan menggunakan uji chisquare pada tingkat kepercayaan $95 \%(\mathrm{p}<0.05)$ dengan sebagai berikut :

Hasil tabulasi silang pada tabel 8 memperlihatkan bahwa dari 10 responden berpendidikan SD, hanya 2 orang $(20.0 \%)$ yang memiliki sikap baik dan 8 orang $(80.0 \%)$ memiliki sikap kurang. Selanjutnya, dari 16 responden berpendidikan SMP, 12 orang (75.0\%) memiliki sikap baik, dan 4 orang (25.4\%) memiliki sikap kurang. Dari 46 responden berpendidikan SMA, 22 orang (47.8\%) memiliki sikap baik dan 24 orang (52.2\%) memiliki sikap kurang. Dari 14 orang berpendidikan diploma, 11 orang (78.6\%) memiliki sikap baik dan 3 orang (21.4\%) memiliki sikap kurang. Dari 4 orang berpendidikan sarjana, seluruhnya memiliki sikap baik (100.0\%).

Hasil uji chi-square memperlihatkan bahwa pada table contingency $2 \times 2$, ada yang memiliki nilai harapan (expected value E) kurang dari 5, sehingga nilai p-value yang dipergunakan adalah nilai Fisher $t_{\text {-count }}=5.743$ dengan p-value -0.017 , lebih kecil dari 0.05 , sehingga dapat disimpulkan bahwa sikap memiliki hubungan signifikan dengan pendidikan. Dengan kata lain, semakin tinggi pendidikan semakin baik sikap dalam memberikan ASI eksklusif.

\section{PEMBAHASAN}

\section{Hubungan Pengetahuan Terhadap Tindakan pemberian ASI Eksklusif}

Hasil penelitian ini sejalan dengan penelitian Nova, Fakultas Kedokteran Universitas Muhammadiyah Surakarta 2014, Hubungan Tingkat Pengetahuan Ibu Tentang ASI Dengan Tindakan ASI Eksklusif dan dengan menggunakan uji chi square membuktikan bahwa pengetahuan memiliki hubungan signifikan dengan tindakan pemberian ASI eksklusif. Semakin baik pengetahuan ibu, semakin besar kemungkinan memberikan ASI eksklusif.

Hasil penelitian ini juga sejalan dengan penelitian Mariane Wowor, 2013, Program Studi Ilmu Keperawatan Fakultas Kedokteran Universitas Sam Ratulangi ManadoHubungan Pengetahuan Dan Sikap Dengan Pemberian ASI Eksklusif Pada Ibu Menyusui di Puskesmas Bahu Kota Manado dimana Hasil penelitian menunjukan 33 responden $(86,8 \%)$ memiliki pengetahuan baik. Setelah dilakukan uji statistik dengan menggunakan uji spearman's rho didapatkan hasil $p=0,000<0,05$, sehingga ada hubungan pengetahuan dengan pemberian ASI. Selanjutnya pengetahuan ibu dihubungkan dengan pendidikan diperoleh hasilyang memperlihatkan bahwa dari 14 orang berpendidikan diploma, 12 orang $(85.7 \%)$ berpengetahuan baik dan 2 orang (14.3\%) berpengetahuan kurang. Dari 4 orang berpendidikan sarjana, seluruhnya 
berpengetahuan baik (100.0\%). Hasil uji chisquare memperlihatkan nilai p-value- 0.022 , lebih kecil dari 0.05, sehingga dapat disimpulkan bahwa pengetahuan memiliki hubungan signifikan dengan pendidikan. Dengan kata lain, semakin tinggi pendidikan semakin baik pengetahuan.

Pengetahuan adalah hasil dari tahu, dan ini terjadi setelah orang melakukan penginderaan terhadap objek tertentu. Penginderaan terjadi melalui panca indera manusia, yakni indera penglihatan, pendengaran, penciuman, rasa, dan raba. Sebagian besar pengetahuan manusia diperoleh melalui mata dan telinga. Pengetahuan umumnya datang dari pengalaman, juga bisa didapat dari informasi yang disampaikan oleh guru, orangtua, buku, dan surat kabar. Pengetahuan atau kognitif merupakan domain yang sangat penting untuk terbentuknya tindakan seseorang (Notoadmojo, 2007).

Pengetahuan tentang ASI eksklusif serta motivasi pemberian ASI Eksklusif yang kurang, mempengaruhi prilaku/sikap ibu yang diakibatkan oleh masih melekatnya pengetahuan budaya lokal tentang pemberian makan pada bayi seperti pemberian madu. Perilaku menyusui yang kurang mendukung diantaranya membuang kolostrum karena dianggap tidak bersih dan kotor,pemberian makanan/ minuman sebelum ASI keluar (prelaktal), serta kurangnya rasa percaya diri informan bahwa ASI tidak cukup untuk bayinya.

Faktor pendidikan erat hubungannya dengan pengetahuan, termasuk tentang ASI eksklusif dimana hasil penelitian menunjukkan bahwa semakin tinggi pendidikan semakin baik pengetahuan tentang pemberian ASI eksklusif. Dalam penelitian ini terbukti bahwa mayoritas responden yang memiliki pengetahuan baik adalah responden yang berpendidikan sarjana (100.0\%).

\section{Hubungan Sikap Terhadap Tindakan Pemberian ASI Eksklusif Hasil analisis \\ deskriptif}

memperlihatkan bahwa mayoritas responden memiliki sikap positif tentang ASI eksklusif yakni sebanyak 51 orang $(56.7 \%)$ dan mayoritas responden memberi ASI eksklusif yakni sebanyak 57 orang (63.3\%). Hal ini mengindikasikan bahwa ada hubungan antara sikap dengan tindakan pemberian ASI eksklusif. Dengan kata lain, semakin baik sikap, semakin besar peluang terjadinya pemberian ASI eksklusif. Hal yang sama juga dikonfirmasi oleh hasil uji chi-square antara sikap dengan tindakan pemberian ASI eksklusif dimana dari dari 51 responden dengan sikap positif, 49 orang (96.1\%) memberi ASI eksklusif dan 2 orang (3.9\%) tidak memberi ASI Eksklusif. Selanjutnya dari 39 responden dengan sikap negatif, 8 orang (20.5\%) memberi ASI eksklusif dan 31 orang (79.5\%) tidak memberi ASI eksklusif. Dengan demikian, mayoritas responden yang memberi ASI eksklusif adalah yang memiliki sikap positif yakni sebanyak 49 orang $(96.1 \%)$. Hasil uji chi-square memperlihatkan bahwa $t$-count $=$ 51.113 dengan p-value -0.000 , lebih kecil dari 0.05 , sehingga dapat disimpulkan bahwa sikap memiliki hubungan signifikan dengan tindakan pemberian ASI eksklusif

Selanjutnya sikap ibu dalam memberikan ASI eksklusif dihubungkan dengan pendidikan, diperoleh hasil dari 14 orang berpendidikan diploma, 11 orang $(78.6 \%)$ memiliki sikap baik dan 3 orang (21.4\%) memiliki sikap kurang. Dari 4 orang berpendidikan sarjana, seluruhnya memiliki sikap baik (100.0\%). Hasil uji chi-square memperlihatkan bahwanilai p-value 0.017, lebih kecil dari 0.05 , sehingga dapat disimpulkan bahwa sikap memiliki hubungan signifikan dengan pendidikan. Dengan kata lain, semakin tinggi pendidikan semakin baik sikap dalam memberikan ASI eksklusif.

Pengetahuan berperan penting sebagai faktor penentu usia menarche remaja putri. Menurunnya usia menarche menandakan adanya perbaikan faktor-faktor yang berhubungan dengan kesehatan dimana kondisi ini tampak pada usia menarche anak yang lebih cepat dari ibunya. Pengetahuan dapat mempengaruhi kecepatan pertumbuhan badan anak sehingga mempengaruhi waktu menarchenya (Luigi, 2010). Penelitian yang dilakukan Putri pada tahun 2009 menyatakan bahwa terdapat hubungan pengetahuan (usia menstruasi pertama ibu) dengan usia menarche pada anak.

Faktor pendidikan erat hubungannya dengan sikap dalam pemberian ASI eksklusif dimana hasil penelitian menunjukkan bahwa semakin tinggi pendidikan semakin baik sikap responden dalam pemberian ASI eksklusif. Dalam penelitian ini terbukti bahwa mayoritas 
responden yang memiliki sikap baik adalah responden yang berpendidikan sarjana (100.0\%). Sejalan dengan telaah Spaulding (2007) terhadap beberapa penelitian bahwa ibu dengan pendidikan tinggi memiliki keinginan untuk memberikan ASI eksklusif kepada bayinya dibandingkan ibu yang berpendidikan rendah. Ibu dengan pendidikan tinggi saat ini lebih mudah untuk mencari informasi tentang menyusui, ibu lebih cerdas dalam memutuskan yang terbaik bagi bayinya. Ibu yang berpendidikan tinggi juga akan lebih cerdas menyikapi berbagai promosi susu formula. Sedangkan ibu yang berpendidikan rendah cenderung lebih mudah mempercayai informasi susu formula. Ibu menganggap bahwa anak mereka akan lebih terlihat sehat jika diberikan susu formula. Ibu akan berusaha semampu mungkin membeli susu formula untuk diberikan pada bayinya. Dari hasil studi kwalitatif tentang praktek keberhasilan dan kegagalan ASI eksklusif di Jakarta tahun 2009, menunjukkan bahawa yang sering menjadi korban iklan susu dan kampanye susu adalah ibu-ibu yang berpendidikan rendah (Syafiq, 2010).

Berdasarkan hasil penelitian dan teori yang relevan di atas, penulis mengasumsikan bahwa ada hubungan antara hasil penelitian dengan teori pendukung tentang pengaruh pengetahuan dan sikap ibu dengan tindakan pemberian ASI eksklusif.

\section{KESIMPULAN DAN SARAN Kesimpulan}

Berdasarkan hasil penelitian dan analisis data yang telah dilakukan tentang hubungan pengetahuan dan sikap dengan tindakan pemberian ASI eksklusif di wilayah kerja Puskesmas Binjai Selatan 2017, dapat disimpulkan bahwa :

1. Pengetahuan ibu tentang ASI eksklusif memiliki hubungan signifikan dengan tindakan pemberian ASI eksklusif sehingga dapat disimpulkan bahwa semakin baik pengetahuan semakin besar peluang memberikan ASI eksklusif $(\mathrm{p}<0.05)$.

2. Sikap memiliki hubungan signifikan dengan tindakan pemberian ASI eksklusif sehingga dapat disimpulkan bahwa semakin positif sikap pengetahuan semakin besar peluang memberikan ASI eksklusif $(\mathrm{p}<0.05)$.
3. Pengetahuan dan sikap memiliki hubungan signifikan dengan tindakan pemberian ASI eksklusif sehingga semakin baik pengetahuan dan sikap, semakin baik pula tindakan pemberian ASI eksklusif.

4. Pengetahuan, sikap dan tindakan pemberian ASI eksklusif memiliki hubungan signifikan dengan pendidikan sehingga dapat disimpulkan bahwa semakin tinggi pendidikan, semakin baik pengetahuan, sikap dan tindakan pemberian ASI eksklusif.

\section{Saran}

Mengingat hasil penelitian ini menggambarkan adanya hubungan antara pengetahuan dan sikap dengan tindakan pemberian ASI eksklusif, maka dengan ini disampaikan saran-saran sebagai berikut :

1. Kepada Petugas Kesehatan Puskesmas Rambung Kecamatan Binjai Selatan, disarankan untukmemaksimalkan peran dan tanggung jawabnya juga dengan meningkatkan peran kader posyandu yang dianggap perpanjangan tangan petugas kesehatan dan dekat dengan masyarakat untuk menyampaikan informasi kesehatan terutama tentang ASI eksklusif.

2. Kepada Dinas Kesehatan Kota Binjai agar melakukan pengawasan peredaran susu formula dan menindaklanjuti penyalahgunaan pemberian susu formula kepada bayi yang baru lahir serta pengawasan pemberian ASI eksklusif oleh bidan kepada ibu dengan cara memantau pemberian ASI melalui KMS setiap kegiatan posyandu.

3. Kepada peneliti lain, disarankan untuk melakukan penelitian sejenis dengan skala penelitian yang lebih luas untuk mendapatkan hasil penelitian terbaru yang lebih akurat guna meningkatkan kesehatan sejak dini dengan pemberian ASI eksklusif dan adanya upaya promosi kesehatan sebagai sarana yang mendukung program ASI eksklusif.

\section{DAFTAR PUSTAKA}

Azwar, S. (2003). Reliabilitas dan Validitas. Cetakan IV. Yogyakarta: Pustaka Pelajar.

Depkes RI. (1994). Deklarasi Dunia Tentang ASI. Jakarta: Dirjen Bina Gizi Masyarakat dan Dirjen Penyuluhan Kesehatan Masyarakat. 
Harnowo. (2012). Hanya 33,6\% Bayi Di Indonesia yang Dapat ASI Eksklusif, Sumber : www.detikhealth.com. Diakses tanggal 5 Januari 2013.

Notoatmodjo. (2010). Promosi Kesehatan Teori Dan Aplikasi, Penerbit Rineka Cipta Jakarta.

. (2007). Promosi Kesehatan dan Ilmu Perilaku. Jakarta : Rineka Cipta.

Nurheti. (2010). Keajaiban ASI- Makanan Terbaik untuk Kesehatan, Kecerdasan, dan Kelincahan Si Kecil. Yogyakarta: CV Andi.
Roesli, (2008). Mengenal ASI eksklusif. Jakarta: Trubus Agriwidya, Anggota IKAPI

Roesli, U. (2008). Inisiasi Menyusui Dini Plus ASI Eksklusif, Pustaka Bunda, Jakarta.

UNICEF. (2011). ASI Eksklusif Tekan Angka Kematian Bayi Indonesia dalam http://situs.kesrepro.info/kia/agu/2006/kia 03.htm 